\title{
Capital Market as a Critical Source for Attracting Funding and Its Interrelationship with Money Market
}

\author{
David Gamkrelidze \\ $\mathrm{PhD}$ Student, Institute of Economics and Business, Ilia State University
}

\begin{abstract}
The development of local capital market as a means of rising additional financial sources for corporations has long been an important economic policy priority for many countries. Over the past years, we see many countries implementing significant reforms to facilitate capital market development. Typically, capital market reform is not carried out separately, but represents one specific part of a large chain of reforms aimed at closer integration with outside counterparties.

Our research reviews the benefits and value of developing local capital markets. We also focus on the challenges of market development, the necessary prerequisites, and the potential repercussions \& unintended consequences of market development. We focus on bond \& equity markets, as well as money and derivative markets. The aim of the study is to determine the sequential steps for financial market development and the relationship between money and capital markets in this regard - the development of former one establishes the foundation encouraging the advancement and progress for the other, or the two markets function as competitors?
\end{abstract}

All in all, the modern world has repeatedly been convinced of the need for a more developed financial markets across the countries. This is evidenced by the recent crisis caused by the Covid-19 pandemic and the difficulties to access to finance in many countries. In the corporate sector, it has become today's common sense that cash has become king across the countries and world global markets. In light with the Covid-19 pandemic and stock markets diving thereby, investors 'raising concern for the safety of their cash has been actualized. The severity of the current situation is a challenge not only for private companies, but also for governments, central banks and other regulators.

Accordingly, the issues reviewed in our paper will be of particular interest to an audience interested in the development of deep and comprehensive financial markets.

Keywords: Financial Market, Financial Instruments, Financial Institutions, Capital Market, Money Market, Cash Management

This work was supported by Shota Rustaveli National Science Foundation (SRNSF)

[PHDF 18-492; "International Financial Markets and Capital Market Development in Georgia"] 